International Journal of English Literature and Social Sciences
Vol-7, Issue-1; Jan-Feb, 2022
Journal Home Page Available: https://ijels.com/
Journal DOI: $10.22161 /$ ijels

Peer-Reviewed Journal

\title{
Narrative Techniques in Ernest Hemingway's Shorter Fiction
}

\author{
Dr. Proteeka Pratap
}

Department of English, Jai Narain Vyas University, Jodhpur, Rajasthan.

Received: 03 Dec 2021; Received in revised form: 16 Jan 2022; Accepted: 21 Jan 2022; Available online: 31 Jan 2022 (C)2022 The Author(s). Published by Infogain Publication. This is an open access article under the CC BY license (https://creativecommons.org/licenses/by/4.0/).

\begin{abstract}
Hemingway is the representative of short stories of modern times. The article focuses on Narrative Technique in the short fiction of Ernest Hemingway. It includes setting, character, point of view, atmosphere, symbolism, style and theme. He looks for social and ethical issues focusing on social criticism of people's attitude. Hemingway supposed to be created out of knowledge and no interfering elements should be allowed to fake that form and deceive that skill. As a consequence, all that can be dispensed with should be pruned off: conference, decoration, rhetoric. It is this propensity of writing that has brought Hemingway approbation as well as disparagement, but it is apparent that the writer knew what he was doing when he himself commented on his aim.
\end{abstract}

Keywords - Narrative Techniques, Clipped, spare style, naturalistic presentation, narration and writing style.

\section{INTRODUCTION}

The narrative means the sequence of events and actions; it is an attainment that fetches jointly mundane details and incredible creations; time and place are incorporated. The narrative allows for the inclusion of actor's reasons for their acts, as well as the causes of happening. (Sarbin: 1986). Hemingway's protagonists are characterized by their untiring dependability. He is susceptible but is not distinct by his susceptibility. Hemingway's male and female are frequently rebellious of what society expects of them: They eat with pleasure, devour adventure and have sex merely and honestly. His first persona was Nick Adams, a young man who accompanies a physician to an American Indian camp and watches the physician use a pocketknife to piece into a woman's stomach and send infant. In the early hours, Nick promises not at all to die. Shortly, he defies demise and the sanity intimidating injuries that he receives in Italy during World War I.

Hemingway reiterates, in blind faith, the kneebending exercises for his firm, battle-scarred knee. Impulsively, he comes back to the north woods of Michigan to cure his spirit of the distress of war.
Hemingway himself undergoes an awful knee injury throughout the combat and returned to hunting and fishing in Michigan's northern woods. In his more mature tales, such as "The Snows of Kilimanjaro" and "The Short Happy Life of Francis Macomber," he generates far more multifaceted characters and incidents. "The Snows of Kilimanjaro" is a stylistic, explores the power of deep, bracing, interior-monologues, flashbacks as contrasts to sections of present-time narratives, throughout which the protagonist, a writer named Harry, is gradually disappearing of gangrene. Representatively, Harry is also decomposing away because of the venomous nature of his wife's money.

"The day before we had been sniped out of a good place to film from and I had to crawl back holding the small camera to my belly, trying to keep my head lower than my shoulders, hitching along on my elbows, the bullets whacking into the brick wall over my back and twice spurting dirt over me". (Hemingway: 1899, p353) As his life ebbs absent, he realizes that his writing skill has been outgoing tide away for years, as certainly as his life 
is, symbolized by the hyena and the buzzards that stay to banquet on his dead body.

In "The Short Happy Life of Francis Macomber", Macomber undergoes a drastic transformation from a cuckold and coward to a man of substance. But Hemmingway gives the story a twist where Macomber dies right at the time when he feels happier than he has felt in years. This is a triumph of Hemmingway's art. Again in "The Snows of Kilimanjaro", the central character Harry is shown hopelessly dejected towards life. He feels he has wasted his time and talent on luxuries and procrastination by marrying a wealthy woman. Here the art of narration of Hemmingway, which is first persona, reaches its culmination when Harry dreams of the Snows of Kilimanjaro which is the highest peak in Africa which means "the house of God." There is also a power use of images and symbols in the story. The vulture and Hyena are the symbols of death. The wound of Harry, the gangrene, is the depiction of art decaying at the hands of a society where money and power dominate. Such a society kills the soul of man and thrives on the superficial and rotten dogmas of greed, lust and fear.

"A Clean Well-Lighted Place" and "Hills Like White Elephants" are illustrations of Hemmingway's most pareddown style, in which he eliminates himself from the task of narration. Again, a setting of gloom and sorrow can be seen. A powerful image of NADA is used which means NOTHINGNESS. What is Life...nothing. It gives nothing. It has nothing to offer. This one comes to know only when one gets old and is counting his days when death finally will take him. Paradoxically, death too is not in one's hand. But once this realization dawns that life is nothingness, it gets difficult to carry on with. This is well depicted in A Clean Well-Lighted Place. In, "The Hills Like White Elephants" the man insists the girl for an abortion, yet the word "abortion" has not been used even once. Isn't this a triumph of Hemmingway's art!! Here we see the use of Hemmingway's poignant iceberg theory which states that like iceberg only $1 / 8^{\text {th }}$ part is visible, but the real and substantial lies hidden. In the same way, and he himself stated this...that the omitted part would strengthen the story. Its left for the readers to understand. And when the reader comprehends the deeper meaning, that gives him more satisfaction of reading any story.

Hemingway is renowned for his standard fiction and his inconspicuous style of writing even among those who have never read him. Several people imagined that everybody is believed to write in the brief, abrupt style of Hemingway, but this isn't the case. Each word wants to calculate regardless of your style. The words that compose abundant, lyrical sentences are still mandatory to do their jobs along the way and having a complicated method is no reason for stuffing. Hemingway's famous story is "Hills Like White Elephants" in which a pair discusses an abortion without ever declaring the word. It's a magnum opus of delicacy and an outstanding session in how to write about sensitive experiences without succumbing to melodrama. We lastly study that the girl's nickname is "Jig." Ultimately we learn that they are in the cafe of a train station in Spain. But Hemingway tells us zilch about them or about their past or about their future. There is no description of them. We don't know their ages. We know virtually nothing about them. The only knowledge that we have about them is what we learn from their dialogue; thus this story must be read very carefully. He chose a concise technique to present his themes.

Hemingway's applies the objective point of view in which we as readers are never allowed introspection of characters' hearts also supplies a motivating lesson in how to imply discussion, descriptions and the events of the characters to express story and meaning. The tale is influential examples of the writing axiom that you should show instead of telling. Hemingway's life and movements incorporated safaris to Africa and time spent among other writers and artists in Paris and provided the backdrop for several of his tales. Every life is predominant with dominant experiences, burly feelings and convincing people and associations and you can draw on those things to add deepness to your fiction. Hemingway's style, which is sometimes burlesque as stilted and flat and some of his attitudes such as the treatment of women in his fiction and the stress on tremendously mannish pursuits like big game hunting have made him a contentious figure in contemporary period. Nevertheless, his imaginary tale has stood the test of time and critical scrutiny.

An outstanding illustration of Hemingway's style is found in "A Clean, Well-Lighted Place." In this story, there is no maudlin sentimentality; the plot is simple, yet highly multifaceted and thorny. Fundamentally, characteristic features of Hemingway novels or short stories are written in plain, straight, unembellished prose. Perhaps, the style flourished because of his early journalistic training. The actuality, though, is this: Before Hemingway started publishing his short stories and sketches, American writers affected British mannerisms. Adjectives mounded on top of one another; adverbs tripped over each other. Colons congested the gush of even small paragraphs and the overabundance of semicolons frequently caused readers to fling their hands in frustration.

Hemingway has frequently been illustrated as a master of conversation; in tale after tale, novel after novel, readers and critics have remarked, "This is the way that 
these characters would really talk." Yet, a secure examination of his dialogue reveals that this is seldom the way people actually talk. The result is accomplished, rather, by calculated stress and replication that makes us remember what has been said. On this evening "I was walking home from the censorship office to the Florida Hotel and it was raining. So about halfway home I got sick of the rain and stopped into Chicopee's for a quick one. It was the second winter of shelling in the siege of Madrid and everything was short including tobacco and people's tempers and you were a little hungry all the time and would become suddenly and unreasonably irritated at things you could do nothing about such as the weather. I should have gone on home." (Hemingway: 1899, p346)

Hemingway provides the readers two contrasted portraits which have taken place during the war, the contrast between the time of war and the time of peace. The atmosphere was dejected beneath the panic of decease, no one has the want to laugh or even smile, the weather was dark and the hands were on the guns "I remembered the flit gun man with his grey wax hands and his grey wax face, his arms spread wide and his legs drawn up and he did look a little like a butterfly" (Hemingway, p.121). The theme of war is employed by the writer to complicated that in "The Butterfly and the Tank," the anguish seems to be much less traumatic; the narrator is now sipping alcohol in the bar, where the assassinate was dedicated, looking out at the bright morning sunlight. This enlighten at the last scene of the story, though, does not necessarily show how bright the narrator's heart is. Though, there is a lot of concealed connotations and signs that demand the vigorous participation of the person who reads to grab the meaning of Hemingway. "Old Man at the Bridge" is one of the works that completely illustrates the genuine meanings disguised in the apparent simplicity (Amrollahi \& Faghfori: 2015, p195). Hemingway was one of the modernist writers; the spotlight is on the techniques that Modernism had at that time to narrate the short stories.

Modernism was an age of disbelieve and distrust. There was indecision concerning every matter even the spiritual ones. For Hemingway, the reader supposed to get the whole picture that he drew. He created his narrators in agreement with what he truly saw. This procedure becomes comprehensible when Hemingway articulates his themes in the literary work. The narrator describes the events and sometimes includes an understanding for the characters' actions into the dialogue. Hemingway creates the reader look much deeper into the dialogue, forcing him/her to understand the character's words. Hemingway brought up arguments that have been going on for a truly long time as in his stories "The Butterfly and the Tank", "Old man at the Bridge" and "Night before Battle " which deal with the thought of decease and emotional pressure that comes with making conclusions. Hemingway's tales twisted normal citizens into philosophers, inquiring their own method and the paths a new society should follow. The lessons are very lucid when he calls for the end of the civil war and the hope of tranquility without submitting to the predictability of death. Hemingway was also motivation to some people, he kept on writing even though he was psychologically unbalanced and to some people that made his stories even more interesting. Hemingway has vast experienced war and adventure as Jing Li, states that Hemingway from his dreadful life has found a new vocabulary for The Lost Generation. He lived in a time full of brutality, pain, blood and antagonism. Virtually his works and his experiences are undividable and have been entangled in many aspects. Looking back through his major works, there is no exception that Hemingway poured his war experiences into his literature works. However, his viewpoints on war were not stable but underwent an everchanging process. (Li, 2014).

Since Modernism concerted on the text and its analysis more than the biography of the author, Hemingway was famous by using the kind of literary style which gives the reader the audacity to extrapolate the deeper meaning of the story rather than focusing on the surface exhibition. This style is called "Iceberg Theory". The Iceberg Theory is the writing style which Hemingway used for the reason that his journalistic career influenced him. He concentrated on the surface elements without discussing the underlying themes explicitly. He assumed that the accurate meaning of a piece of writing should not be palpable from the surface tale and the reader should see below it. Oliver (1999) talked about in his book about Hemingway's life and works that Hemingway himself summarized his theory as: If a writer of prose knows sufficient of what he is writing about he may omit things that he knows and the reader, if the writer is writing really sufficient, will have a emotion of those things as powerfully as though the writer had stated them.

\section{CONCLUSION}

A great deal has been written about Hemingway's unique style. In fact, the great stylists of $20^{\text {th }}$ American literature are Hemingway and the styles of the writer are so infinitely dissimilar that there can be no contrast. The parodies of Hemingway's writing style are possibly the more fun to read because of Hemingway's eventual simplicity and because he so often used the same style and the same themes in much of his work. He himself had been a journalist and so touches upon every detail of the setting yet hiding its deeper meaning, leaving for the reader for 
some mental churning. Such a unique style of writing is certainly like a Kohinoor in his crown. All this makes him the greatest writer of modern American fiction.

\section{REFERENCES}

[1] Benson, Jackson. (1975). The short stories of Ernest Hemingway: critical essays Durham, N.C: Duke University Press.

[2] Jasná, Eva. (2010). Theme of Dignity in the Work of Ernest Hemingway. Bachelor's degree programmer Archive of Thesis Philology/English Language and Literature.

[3] Li, Jing. (2014). The Impacts of Wars on Earnest Hemingway's Works Department of Foreign Languages, Inner Mongolia University.

[4] Moritz, N. (1968). Hemingway's narrative technique as a short story writer V. 168 Pages: 9.

[5] Oliver, Charles M. (1999). Ernest Hemingway A to Z: The Essential Reference to the Life and Work. New York: Checkmark.

[6] Robinson, K. K. (2003). Testimony of Trauma: Ernest Hemingway's Narrative Progression in . South Florida: Department of English Art and Science.

[7] Sarbin, T. R. (1986). The narrative as a root metaphor in psychology. In T. R. Sarbin (Ed.), Narrative psychology: The storied nature of human conduct. New York: Praeger P.9

[8] Samuelson, Scott. (1992). Study Guide for The Short Stories of Ernest Hemingway, English Department, Ricks College, Rexburg, Idaho.

[9] Simon, Sara. (2013). A Reporter's Story: The Significance of Hemingway's Early Work in Journalism.

[10] Stewart, M. (2009). Modernism and Tradition in Ernest Hemingway's In Our Time. New York: LUS Press.

[11] Yalom, M. (1971). Ernest Hemingway-A Psychiatric View. England: Arch Gen Psychiatry 